\title{
Dampak Masuknya Turis Asing Terhadap Budaya Asli Masyarakat Sekitar Lokasi Pantai Lakey Desa Hu'u Kabupaten Dompu Mintasrihardi' ${ }^{1}$, Selva ${ }^{2}$, Nurlaila fitriyah suyatno ${ }^{3}$ \\ ${ }^{1}$ Prodi Administrasi Publik, Universitas Muhammadiyah Mataram , Indonesia \\ ${ }^{2}$ Prodi Administrasi Bisnis, Universitas Muhammadiyah Mataram, Indonesia \\ ${ }^{3}$ Prodi Administrasi Publik, Universitas Muhammadiyah Mataram, Indonesia
}

\section{INFO ARTIKEL}

Riwayat Artikel:

Diterima: $15-07-2018$

Disetujui: 19-07-2018

\section{Kata Kunci:}

1. Dampak

2. Budaya Asing

3. Masyarakat Lokal

\section{ABSTRAK}

Abstrak: Penelitian ini bertujuan untuk mendeskripsikan dampak adanya budaya asing terhadap budaya asli masyarakat sekitar lokasi pantai Lakey yang ditinjau dari dampak positif dan negatif adanya budaya asing di sekitaran pantai Lakey desa Hu'u kabupaten Dompu. Penelitian ini menggunakan jenis data kualitatif, data dalam penelitian ini berupa kata-kata dan tindakan yang diperoleh dengan cara observasi, wawancara dan dokumentasi. Instrumen utama dalam penelitian ini adalah data dengan dibantu pedoman observasi, dokumentasi dan wawancara. Alat bantu penelitian yang digunakan adalah berupa kamera digital dan peralatan tulis. Keabsahan data diperoleh dengan teknik triangulasi. Teknik analisis data yang digunakan adalah deskriptif. Langkah analisis data dengan cara reduksi data, penyajian data dan menarik kesimpulan atau verifikasi.

Hasil penelitian ini menunjukan bahwa 1) Tradisi gaya hidup kebarat-baratan salah satunya adalah cara berpakaian yang tidak sopan bagi para perempuan seperti memakai celana atau rok pendek serta baju yang tidak bisa menutup semua badan bahkan ada juga yang memakai bikini ( pakaian dalam saja). Mereka tidak merasa risih atau malu terhadap lawan jenisnya ketika mereka menggunakan pakaian pendek atau tidak menutup seluruh badanya. Hal ini dianggap biasa bagi mereka sehingga mereka merasa tidak takut dengan dampak dari berpakaian pendek. 2) Masih menerapkan pola hidup konsumtif sebagian masyarakat masih suka menghamburhamburkan uang hanya untuk melakukan hal negatif seperti pesta minuman keras ketika ada acara-acara tertentu, mereka tidak enggan untuk mengeluarkan uang banyak hanya untuk mabuk-mabukan. Bukan hanya untuk membeli minuman keras mereka juga sering membeli kebutuhan yang tidak penting seperti membeli baju yang harganya cukup mahal hanya untuk menghabiskan uangnya saja. 3) Adanya turis asing juga mengakibatkan kesenjangan sosial, pada umumnya masyarakat pilih-pilih teman bergaul hal ini membuat masyarakat miskin merasa minder dengan masyarakat yang lebih mampu. Menurut tanggapan masyarakat pantai Lakey bahwa sebagian masyarakat yang bermmodal atau kaya mereka lebih mengurangi bergaul dengan yang kurang mampu karena dianggap mereka kurang berpengalaman dalam dunia bisnis. Sampai saat ini juga masih belum ada campur tangan pemerintah dalam menanggapi hal ini. 4) Namun dari sekian banyak dampak negatif yang dijelaskan oleh masyarakat Lakey ada juga dampak positif yang dirasakan oleh 
masyarakat yaitu terciptanya lapangan kerja dan lain-lain.

Dalam penelitian ini banyak masyarakat yang mengeluh dari adanya dampak budaya asing, sehingga masyarakat khawatir akan punah nilai-nilai budaya asli masyarakat iu sendiri.

Keyword
1. Impact
2. Foreign Culture
3. Local Communities

\section{Abstract}

This study aims to describe the impact of foreign culture on the indigenous culture of the community around the Lakey beach location in terms of the positive and negative effects of foreign cultures around Lakey beach in Hu'u village, Dompu district. This study uses a type of qualitative data, the data in this study are in the form of words and actions obtained by observation, interviews and documentation. The main instrument in this study is data assisted by observation, documentation and interview guidelines. The research aids used are in the form of digital cameras and writing equipment. The validity of the data is obtained by triangulation techniques. The data analysis technique used is descriptive. Steps for analyzing data by reducing data, presenting data and drawing conclusions or verification.

The results of this study show that 1) Westernized lifestyle tradition is one of them is a way of dressing that is not polite for women such as wearing pants or short skirts and clothes that cannot cover all bodies and some even wear a bikini (underwear only). They do not feel uncomfortable or ashamed of the opposite sex when they wear short clothing or do not cover their entire body. This is considered normal for them so they feel unafraid of the effects of short dressing. 2) Still adopting a consumptive lifestyle, some people still waste money just to do negative things like binge drinking when there are certain events, they are not reluctant to spend a lot of money just to get drunk. Not only to buy liquor they also often buy nonessential needs such as buying clothes that are quite expensive only to spend money. 3) The presence of foreign tourists also results in social inequality, in general, the people are picky about their associations, making the poor feel inferior to the more capable people. According to the Lakey beach community's response that some of the people who have capital or wealth are more likely to reduce associations with the less fortunate because they are considered less experienced in the business world. Until now there has also been no government intervention in responding to this. 4) But of the many negative impacts described by the Lakey community there is also a positive impact felt by the community, namely the creation of jobs and others.

In this study many people complained of the impact of foreign cultures, so that people were worried about extinction of their own indigenous cultural values. 


\section{Latar Belakang}

Seiring dengan pertambahan populasi penduduk dunia yang cukup pesat, mengakibatkan bertambahnya kecenderungan pasar potensial yang akan melakukan perjalanan. Terlebih lagi, perjalanan bukan hanya sekedar hiburan, akan tetapi mempunyai tujuan tertentu yang akan membawa pengaruh yang cukup besar terhadap pribadi, keluarga maupun lingkunganya dalam decade (10 tahun) terakhir ini. Hal ini merupakan sebuah harapan untuk masa depan, dimana kemajuan akan berlanjut baik nantinya. Pengaruh interaksi yang timbul antara pengunjung dilingkungan tuan rumah akan bertambah, terutama ketika wisatawan yang berasal dari Negara industri maju mengunjungi negara sedang berkembang. Tetapi tidak luput dengan apa yang menjadi Kebijakan Pariwisata, Kebijakan Pariwisata merupakan perencanaan jangka panjang yang mencakup tujuan pembangunan atau prosedur pencapaian tujuan tersebut dibuat dalam pernyataan-pernyataan formal seperti hukumdan dokumen-dokumen resmi lainya. Kebijakan yang dibuat oleh Pemerintah harus sepenuhnya dijadikan panduan dan ditaati oleh para semua stakeholders (pemangku kepentingan). Kebijakan-kebijakan yang harus dibuat dalam pariwisata adalah kebijakan yang berhubungan dengan pertumbuhan ekonomi, peningkatan kesempatan kerja dan hubungan politik ( Biederman 2007)

Semua tren (gaya mutakhir) ini dapat membawa pengaruh positif bahkan negatif itu dapat dilihat dari akibat yang ditimbulkanya. Sementara perkembangan sosial kultural akan menjadi faktor yang mempengaruhi industri perjalanan yakni perubahan demografi yang dapat membawa pengaruh lain. Hasil dari perubahan ini akan menambah nilai produk perjalanan dalam hubungan terbesar ialah untuk semua bentuk kesenangan perjalanan. Seiring perkembangan industri, akan ada keuntungan tersendiri bagi masyarakat sekitar daerah wisata dan perkembangan untuk karyawan penyalur perjalanan untuk semua tipe peralatan yang dibutuhkan oleh industri transportasi dan akomodasi.

Indonesia adalah bangsa yang majemuk, terkenal dengan keanekaragaman dan keunikanya. Kebudayaan yang dimiliki oleh bangsa Indonesia merupakan kebudayaan yang majemuk pula dan sangat kaya ragamnya. Indonesia sendiri terdiri dari berbagai suku bangsa, yang mendiami belasan ribu pulau.
Masing-masing suku memiliki keanekaragaman budaya tersendiri. Disetiap budaya tersebut terdapat nilai-nilai sosial dan seni yang tinggi. Pada kondisi saat ini kebudayaan mulai ditinggalkan bahkan sebagian masyarakat Indonesia malu akan kebudayaan sebagai jati diri sebuah bangsa.

Perbedaan yang terjadi dalam kebudayaan Indonesia dikarenakan proses pertumbuhan yang berbeda dan pengaruh dari budaya lain yang ikut bercampur didalamnya. Dilihat dari perkembangan zaman di era globalisasi sekarang amatlah pesat karena penemuan-penemuan baru disegala bidang. Penemuan-penemuan baru di dunia teknologi maupun mencontoh dari perilaku wisatawan asing sehari-hari membuat kita semakin menghindari budaya asli Dompu.

Dari penjelasan diatas dapat di lihat bahwa kebudayaan di Indonesia khususnya di pantai Lakey desa Hu'u Kabupaten Dompu sudah mulai memudar karena adanya budaya asing yang semakin kuat yang dianggap ngetren (gaya mutakhir) bagi para remaja atau masyarakat sekitar kawasan pantai Lakey. Terlebih karena budaya asing dianggap lebih mudah diikuti daripada budaya asli Indonesia itu sendiri. Selain hal tersebut yang telah membudaya ada juga fenomena lain di era globalisasi yang terjadi di Indonesia khususnya di kalangan remaja, dimana para remaja cenderung meniru kebudayaan barat. Jika kita bandingkan masyarakat Indonesia pada zaman dahulu dan zaman sekarang sangat beda jauh karena memang masyarakat zaman sekarang telah banyak mengikuti kehidupan orang barat dibandingkan zaman dahulu yang masih kental dengan adat istiadat dan Indonesia dikenal sebagai Negara multi etnis dan agama, dari situlah Indonesia memiliki ragam budaya berbeda-beda. Di setiap budaya tersebut terdapat nilai nilai sosial dan seni yang tinggi. Pada saat ini kebudayaan di Indonesia kian memudar secara perlahan. Hal ini di karenakan semakin berkembangnya teknologi yang akhir nya dapat memberikan dampak negatif terhadap kebudayaan asli Indonesia. Dengan banyak datangnya turis asing, kebudayaan barat dapat dengan mudah masuk ke indonesia, sehingga dimulai mengubah pola pikir dan perilaku masyarakat Indonesia.

Kebudayaan barat yang masuk ke Indonesia sebenarnya memiliki dampak positif dan negatif bagi masyarakat indonesia. Dampak 
positif misalnya, kreatifitas, inovasi pengembangan ilmu pengetahuan dan teknologi, hidup disiplin dan profesionalitas dan lain lain. Dampak negatifnya kebudayaan asing atau barat terhadap masyarakat Indonesia khususnya kalangan remaja sudah sampai tahap memprihatinkan karena ada kecenderungan para remaja sudah melupakan kebudayaan bangsanya sendiri. Budaya ikut-ikutan atau latah terhadap cara berpakaian misalnya, para remaja tidak ingin dikatakan kuno, kampungan kalau tidak mengikuti cara berpakaian ala barat karena dinilai modern, tren dan mengikuti perkembangan zaman meski memperlihatkan auratnya yang dilarang oleh ajaran agama islam yang bermayoritas di Dompu khususnya atau di NTB pada umumnya maupun bertentangan dengan adat istiadat masyarakat sekitar pantai Lakey Kecamatan Hu'u Kabupaten Dompu secara turun menurun.

Selain cara berpakain dan mode, pergaulan bebas dan cara berhura-hura dikalangan remaja yang dilihat sebagai prilaku yang menyimpang baik secara agama maupun sosial juga menjadi masalah bagi kebudayaan di Indonesia. Umumnya kalangan remaja Indonesia berperilaku ikut-ikutan tanpa selektif sesuai dengan nilai-nilai agama yang dianut dan adat kebiasaan yang mereka miliki.

Para remaja juga merasa bahwa kebudayaan di negerinya sendiri terkesan jauh dari modernisasi. Sehingga para remaja merasa gengsi kalau tidak mengikuti perkembangan zaman meskipun bertentangan dengan nilai-nilai ajaran agama budayanya. Sehingga pada akhirnya para remaja lebih menyukai kebudayaan barat, dibandingkan dengan kebudayaan masyarakat asli Dompu. Indonesia memiliki berbagai suku dan budaya sehingga banyak turis asing yang ingin tahu lebih dalam terkait dengan budaya Indonesia tetapi masyarakat Indonesia tidak menyadari bahwa orang luar ingin tahu lebih tentang budaya Indonesia tersebut malah sebaliknya masyarakat Indonesia mengikuti budaya luar, Indonesia yang kaya akan keberagaman suku, budaya dan adat istiadat memberikan warna tersendiri untuk menarik minat orang asing datang ke Indonesia termasuk destinasi wisata di Nusa Tenggara Barat, salah satu destinasi wisata yang diminati turis asing adalah pantai Lakey yang terletak di bagian selatan Kabupaten Dompu.

Pantai Lakey dikenal dengan ombaknya yang sangat bagus untuk bermain selancar selain dari pantainya yang sangat indah dan bersih serta menakjubkan, tak sedikit wisatawan asing datang untuk menjajal ombak besarnya, akan tetapi dari banyaknya turis asing datang maka sedikit demi sedikit kebudayaan atau adat istiadat asli masyarkat semakin hilang pula. Banyaknya para remaja yang membaur bersama turis sehingga mereka cenderung melanggar norma kebudayaan asli mereka

Sehingga penelitian ini dapat difokuskan pada dampak adanya turis asing yang semakin perlahan budayanya ditiru oleh masyarakat sekitar dan membuat budaya asli dompu ditinggalkan. Penelitian ini berjudul "Dampak Masuknya Turis Asing Terhadap Budaya Asli Masyarakat Sekitar Lokasi Pantai Lakey Desa Hu'u Kabupaten Dompu".

\section{Tinjauan Pustaka}

\section{a. Administrasi Publik}

Definisi Administrasi Publik menurut Chandler dan Plano dalam Pasolong, Harbani (2011:7), mengatakan bahwa Administrasi Publik adalah proses dimana Sumber Daya dan personel Publik diorganisir dan dikoordinasikan untuk memformulasikan, mengimplementasikan, dan mengelola (manage) keputusan-keputusan dalam Kebijakan Publik. Konsep Administrasi Publik di Indonesia pada dasarnya bukanlah konsep yang baru, karena konsep administrasi Publik sudah ada sejak dari dulu, hanya para pakar yang mengganti istilah Administrasi Publik menjadi Administrasi Negara. Begitu pula buku-buku asing misalnya yang berjudul "Public Adminitration" diganti menjadi Administrasi Negara. Jika ada para pakar yang mengatakan bahwa Administrasi Negara perlu direformasi menjadi Administrasi Publik, maka itu dapat dikatakan kesalahan berfikir, karena Administrasi Publik sudah ada sejak dari dulu. (Pasolong, 2012:55).

Chandler \& Plano dalam Pasolong (2012:55), menjelaskan bahwa Administrasi Publik merupakan Seni dan Ilmu yang ditujukan untuk mengatur "Publik Affairs" dan melaksanakan berbagai tugas yang ditentukan. Administrasi Publik sebagai disiplin ilmu bertujuan untuk memecahkan Masalah Publik melalui perbaikan-perbaikan terutama dibidang organisasi, sumberdaya manusia dan keuangan. Menurut Nicholas Hendry dalam Pasolong (2012:56) mendefinisikan "Administrasi Publik adalah suatu kombinasi yang kompleks antara teori 
dan praktik, dengan tujuan mempromosikan pemahaman terhadap pemerintah dalam hubungannya dengan masyarakat yang diperintah, dan juga mendorong kebijakan publik agar lebih responsif terhadap kebutuhan sosial".

George J. Gordo dalam Inu Kencana, (51:2015) Administrasi Publik dapat dirumuskan sebagai seluruh proses yang baik yang dilakukan organisasi maupun perseorangan yang berkaitan dengan penerapan atau pelaksanaan hukum dan peraturan yang dikeluarkan oleh badan legislatif, eksekutif serta peradilan. Administrasi Publik dimaksudkan untuk lebih memahami hubungan pemerintah dengan publik serta meningkatkan responbilitas kebijakan terhadap berbagai kebutuhan publik, dan juga melembagakan praktik-praktik manajerial agar terbiasa melaksanakan suatu kegiatan dengan efektif, efisien dan rasional.

Beberapa definisi Administrasi Publik yang telah dikemukakan oleh para ahli di atas, dapat dipahami bahwa Administrasi Publik adalah kerjasama yang dilakukan oleh sekelompok orang atau lembaga dalam melaksanakan tugas-tugas pemerintahan dalam memenuhi kebutuhan publik secara efesien dan efektif.

\section{b. Pengertian Pariwisata}

Pariwisata adalah salah satu kegiatan yang sangat populer saat ini, bahkan telah menjadi salah satu dari kebutuhan bagi masyarakat di seluruh dunia tak terkecuali di Indonesia. Sebagaimana kita ketahui bahwa Indonesia adalah Negara yang sangat potensial untuk dijadikan destinasi wisata, dikarenakan Indonesia terdiri dari beberapa pulau yang indah dan eksotis serta keanekaragaman jenis flora dan fauna, suku bangsa, bahasa dan budayanya menjadikan keunikan tersendiri yang dapat menarik minat wisatawan untuk datang berkunjung. Indonesia memiliki potensi pariwisata yang luar biasa mulai dari wisata alam, wisata belanja, budaya sampai keagamaan. Belum lagi jika berbicara mengenai potensi alamnya saja. Indonesia memiliki kawasan terumbu karang terkaya di dunia. Kekayaan biota laut tersebar dan menciptakan sekitar ratusan titik selam yang tersebar dari sabang sampai merauke. Industri pariwisata Indonesia tetap tumbuh, bahkan melebihi angka pertumbuhan ekonomi nasional.

Selain itu Indonesia memiliki jumlah kunjungan wisata yang stabil jika dibandingkan dengan Negara yang lain. Menurut data the travel and tourism competitiveness index yang dilansir dari world economic forum (WEF) 2013, Indonesia menonjol dikategori budaya dan warisan sejarah serta kekayaan dan keindahan alam. Indonesia juga diuntungkan oleh semakin meningkatnya minat wisatawan terhadap perjalanan wisata budaya. Pangestu, M.E sebagai Menteri Pariwisata Dan Ekonomi Kreatif di Jakarta (2014) mengatakan " tren wisata budaya menjadi peluang bagi Indonesia untuk lebih mengintegrasikan ekonomi kreatif berbasis budaya sebagai daya tarik pariwisata untuk lebih mendorong pertumbuhan perekonomian nasional, terutama bagi usaha skala kecil dan menengah". Oleh sebab itulah, pengembangan berbagai infrastruktur dan sarana serta prasarana untuk ditingkatkan mengingat saat ini skor pariwisata adalah salah satu sumber peningkat devisa negara. Keramah tamahan penduduk Indonesia yang menjadi salah satu faktor pendukung pengembangan pariwisata selain kekayaan alam dan budayanya, ditambah lagi dengan perkembangan teknologi dan informasi yang canggih dan modern sehingga dengan mudah objek wisata di Indonesia untuk dipromosikan di seluruh dunia.

1. Menurut KBBI: Pariwisata, Pelancongan, Turisme adalah kegiatan yang berhubungan dengan perjalanan untuk rekreasi.

2. Menurut Undang-undang no 10 tahun 2009 tentang Kepariwisataan, Pariwisata adalah "Berbagai macam kegiatan wisata dan didukung fasilitas serta layanan yang disediakan masyarakat setempat, sesama wisatawan, pemerintah, pemerintah daerah dan pengusaha. 
3. Menurut WTO atau World Tourism Organization, Pariwisata adalah kegiatan manusia yang melakukan perjalanan dan tinggal di daerah tujuan di luar lingkungan kesehariannya.

Pengertian pariwisata menurut para ahli: Beberapa ahli juga mengemukakan pengertian Pariwisata, berikut daftar lengkap pengertian Pariwisata menurut para ahli dari luar dan dalam negeri;

a) Spillane (1982)

Pariwisata adalah kegiatan melakukan perjalanan dengan tujuan mendapatkan kenikmatan, mencari kepuasan, mengetahui sesuatu, memperbaiki kesehatan, menikmati olahraga atau istirahat, menunaikan tugas, berziarah dan lain-lain.

b) Meyers (2009)

Pariwisata adalah aktivitas perjalanan yang dilakukan oleh sementara waktu dari tempat tinggal semula ke daerah tujuan dengan alasan bukan untuk menetap atau mencari nafkah melainkan hanya untuk memenuhi rasa ingin tahu, menghabiskan waktu senggang atau libur serta tujuan-tujuan lainnya.

c) Kodhyat (1998)

Pariwisata adalah perjalanan dari suatu tempat ketempat lain, bersifat sementara, dilakukan perorangan atau kelompok, sebagai usaha mencari keseimbangan atau keserasiaan dan kebahagiaan dengan lingkungan dalam dimensi sosial, budaya, alam dan ilmu.

d) Burkart dan Medlik (1987)

Pariwisata sebagai suatu transformasi orang untuk sementara dan dalam jangka waktu jangka pendek ketujuantujuan di luar tempat dimana mereka hidup dan bekerja, dan kegiatankegiatan mereka selama tinggal di tempat-tempat tujuan itu.

e) Mathieson dan Wall (1982)

Mendefinisikan pariwisata sebagai serangkaian aktivitas berupa aktivitas perpindahan orang untuk sementara waktu ke suatu tujuan di luar tempat tinggal maupun tempat kerjanya yang biasa, aktivitas yang dilakukannya selama tinggal di tempat tujuan tersebut dan kemudahan-kemudahan yang disediakan untuk memenuhi kebutuhannya baik selama dalam perjalanan maupun di lokasi tujuannya.

f) Wahab (1975)

Pariwisata adalah salah satu jenis industri baru yang mampu mempercepat pertumbuhan ekonomi dan penyediaan lapangan kerja, peningkatan penghasilan, standar hidup serta menstimulasi sektor-sektor produktif lainnya. Selanjutnya, sebagai sektor yang komplek, pariwisata juga merealisasi industri-industri klasik seperti industri kerajinan tangan dan cinderamata, penginapan dan transportasi.

g) Yoeti (1996:116)

Pariwisata adalah suatu aktivitas manusia yang dilakukan secara sadar yang mendapat pelayanan secara bergantian diantara orang-orang dalam suatu Negara itu sendiri atau diluar negeri, meliputi pendiaman orang-orang dari daerah lain untuk sementara waktu mencari kepuasan yang beraneka ragam dan berbeda dengan apa yang dialaminya, dimana ia memperoleh pekerjaan tetap dan sejumlah kegiatan terutama yang ada kaitannya dengan perekonomian secara langsung berhubungan dengan masuknya orangorang asing melalui lalu lintas di suatu negara tertentu, kota dan daerah. Adapun pengertian lain terkait dengan pengertian pariwisata menurut Yoeti (1996) yaitu Pariwisata merupakan gabungan gejala dan hubungan yang timbul dari interaksi wisatawan, bisnis, pemerintah tuan rumah serta masyarakat tuan rumah dalam proses menarik dan melayani wisatawanwisatawan serta para pengunjung lainnya.

\section{h) Krapt dan Hunziker (1996:112)}

Pariwisata adalah keseluruhan dari gejala-gejala yang ditimbulkan dari perjalanan dan pendiaman orang-orang asing serta penyediaan tempat tinggal 
sementara, asalkan orang asing itu tidak tinggal menetap dan tidak memperoleh penghasilan dari aktivitas yang bersifat sementara.

i) Fleuler (2010)

Pariwisata dalam arti modern adalah fenomena dari zaman sekarang yang pada umumnya didasarkan atas kebutuhan, kesehatan dan pergantian hawa. Sedangkan pada khususnya disebabkan oleh bertambahnya pergaulan berbagai bangsa dan kelas masyarakat manusia sebagai hasil dari perkembangan perniagaan, industri, perdagangan, serta penyempurnaan dari alat-alat pengangkutan.

j) Hunziger dan krapt (1942)

Menyatakan pariwisata adalah keseluruhan jaringan dan gejala-gejala yang berkaitan dengan tinggalnya orang asing disuatu tempat dengan syarat orang tersebut tidak melakukan suatu pekerjaan yang penting (Major Activity) yang memberi keuntungan yang bersifat permanen maupun sementara.

k) Marpaung dan Bahar (2000)

Pariwisata adalah suatu perjalanan yang dilakukan orang untuk sementara waktu, yang diselenggarakan dari suatu tempat ke tempat lain meninggalkan tempatnya semula, dengan suatu perencanaan dan dengan maksud bukan untuk berusaha atau mencari nafkah di tempat yang dikunjungi, tetapi sematamata untuk menikmati kegiatan bertamasya dan rekreasi atau untuk memenuhi keinginan yang beraneka ragam.

1) Richardson and fluker (2004)

Pariwisata merupakan kegiatankegiatan atau orang-orang yang melakukan perjalanan dan tinggal di luar lingkungan mereka selama tidak lebih dari satu tahun berturut-turut untuk bersantai, bisnis dan tujuan lainnya.

m) Soekadijo (1996)

Pariwisata adalah gejala yang komplek dalam masyarakat, didalamnya terdapat hotel, objek wisata, souvenir, pramuwisata, angkutan wisata, biro perjalanan wisata, rumah makan dan banyak lainnya.

n) Suwantoro (1997)

Pariwisata adalah suatu proses kepergiaan sementara dari seseorang atau lebih menuju tempat lain dari luar tempat tinggalnya karena suatu alasan dan bukan untuk melakukan kepergian yang menghasilkan uang.

o) Kusdianto (1996)

Pariwisata adalah suatu susunan organisasi, baik pemerintah maupun swasta yang terkait dalam pengembangan, produksi dan pemasaran produk suatu layanan yang memenuhi kebutuhan dari orang yang sedang bepergian.

p) Gamal (2002)

Pariwisata didefinisikan sebagai bentuk Suatu proses kepergian sementara dari seseorang, lebih menuju ke tempat lain di luar tempat tinggalnya. Dorongan kepergianya adalah karena berbagai kepentingan ekonomi, sosial, budaya, politik, agama, kesehatan maupun kepentingan lain.

Ya, begitulah pariwisata, satu kata yang memiliki makna yang sangat luas, sehingga banyak ahli yang mendefinisikannya. Dari pendapatpendapat diatas. Definisi Pariwisata secara Umum yaitu keseluruhan kegiatan pemerintahan, dunia usaha dan masyarakat untuk mengatur, mengurus dan melayani kebutuhan wisatawan. Definisi Pariwisata secara Teknis yaitu rangkaian kegiatan yang dilakukan manusia baik secara perorangan maupun berkelompok di dalam wilayah negara sendiri atau di negara lain dengan menggunakan jasa dan faktor penunjang lainnya yang diadakan pemerintah, badan usaha dan masyarakat.

\section{c. Pengertian wisatawan}

Wisatawan memiliki beragam motif, minat, ekspektasi, karakteristik sosial, ekonomi, budaya, dan sebagainya menurut Heher (2003). Dengan motif dan latar belakang yang 
berbeda-beda itu mereka menjadi pihak yang menciptakan permintaan produk dan jasa wisata. Peran ini sangat menentukan dan sering diposisikan sebagai jantung kegiatan pariwisata itu sendiri. Wisatawan adalah orang yang mengadakan perjalanan dari tempat kediamannya tanpa menetap di tempat yang didatanginya atau hanya untuk sementara waktu tinggal di tempat yang didatanginya. Organisasi Wisata Dunia World Tourism Organization (WTO), menyebut wisatawan sebagai pelancong yang melakukan perjalanan pendek. Menurut organisasi ini, wisatawan adalah orang yang melakukan perjalanan ke sebuah daerah atau negara asing dan menginap minimal 24 jam atau maksimal enam bulan di tempat tersebut menurut Soekadijo (1997).

Wisatawan adalah konsumen atau pengguna produk dan layanan. Perubahan-perubahan yang terjadi dalam kehidupan mereka berdampak langsung pada kebutuhan wisata, yang dalam hal ini permintaan wisata.

Ciri-ciri wisatawan adalah :

1. Melakukan suatu perjalanan di luar tempat tinggal, sehubungan dengan berbagai keperluan seperti rekreasi, liburan, kesehatan, pendidikan, tugas-tugas, pekerjaan, usaha bisnis, kesenian, ilmu pengetahuan, ibadah, olahraga dan pameran.

2. Melakukan perjalanan dan persinggahan di tempat lain untuk sementara waktu tanpa bermaksud untuk memperoleh penghasilan tetap di tempat yang dikunjungi.

3. Pengertian wisatawan menurut Pendit (2002) yaitu :

4. Orang-orang yang sedang mengadakan perjalanan untuk bersenang-senang, untuk keperluan pribadi, untuk keperluan kesehatan dan sebagainya.

5. Orang-orang yang sedang mengadakan perjalanan untuk maksud menghadiri pertemuan, konferensi, musyawarah, atau di dalam hubungan sebagai utusan berbagai badan atau organisasi (ilmu pengetahuan, administrasi, diplomatik, olahraga, keagamaan, dan sebagainya).
6. Orang-orang yang sedang mengadakan perjalanan dengan maksud bisnis.

7. Pejabat pemerintah dan orang-orang militer beserta keluarganya yang mengadakan perjalanan ke negeri lain. Wisatawan dapat diklasifikasikan dengan menggunakan berbagai dasar, yaitu atas dasar interaksi dan atas dasar kognitif normatif (Murphy: 1985). Pada tipologi atas dasar interaksi, penekanannya adalah sifat-sifat interaksi antara wisatawan dengan masyarakat lokal. Sedangkan tipologi atas dasar kognitifnormatif lebih menekankan pada motivasi yang melatarbelakangi perjalanan. Cohen (1972) mengklasifikasikan wisatawan atas tingkat familiarisasi dari daerah yang akan dikunjungi, serta tingkat pengorganisasian perjalanan wisatanya. Atas dasar ini, Cohen (1972) menggolongkan wisatawan menjadi empat, yaitu :

8. Drifter, adalah wisatawan yang ingin mengunjungi daerah yang sama sekali belum diketahuinya, yang berpergian dalam jumlah kecil.

9. Explorer, adalah wisatawan yang melakukan perjalanan dengan mengatur perjalanannya sendiri, tidak mau mengikuti jalan-jalan wisata yang sudah umum melainkan mencari hal yang tidak umum.

10. Individual mass tourist, adalah wisatawan yang menyerahkan pengaturan perjalanannya kepada agen perjalanan, dan mengunjungi daerah tujuan wisata yang sudah terkenal.

11. Organized mass tourist, adalah wisatawan yang hanya mau mengunjungi daerah tujuan wisata yang sudah terkenal, dengan fasilitas seperti yang dapat ditemuinya di tempat tinggalnya, dan dalam perjalanan selalu dipandu oleh pemandu wisata.

\section{d. Pengertian Budaya}

Budaya adalah suatu cara hidup yang berkembang dan dimiliki bersama oleh sebuah kelompok orang dan diwariskan dari generasi ke generasi. Budaya terbentuk dari banyak unsur yang rumit, termasuk sistem agama dan politik, adat istiadat, bahasa, perkakas, pakaian, bangunan, dan karya seni, 
Bahasa. sebagaimana juga budaya, merupakan bagian tak terpisahkan dari diri manusia sehingga banyak orang cenderung menganggapnya diwariskan secara genetis. ketika seseorang berusaha berkomunikasi dengan orangorang yang berbeda budaya dan menyesuaikan perbedaanperbedaannya, membuktikan bahwa budaya itu dipelajari.

Budaya adalah suatu pola hidup menyeluruh. budaya bersifat kompleks, abstrak, dan luas. Banyak aspek budaya turut menentukan perilaku komunikatif. Unsur-unsur sosial budaya ini tersebar dan meliputi banyak kegiatan sosial manusia. Beberapa alasan mengapa orang mengalami kesulitan ketika berkomunikasi dengan orang dari budaya lain terlihat dalam definisi budaya. Budaya itu sendiri adalah suatu perangkat rumit nilai-nilai yang dipolarisasikan oleh suatu citra yang mengandung pandangan atas keistimewaannya sendiri.

Dengan demikian, budayalah yang menyediakan suatu kerangka yang koheren untuk mengorganisasikan aktivitas seseorang dan memungkinkannya meramalkan perilaku orang lain. kemudian, ditambahkan oleh Bennet (1980) bahwa pengertian budaya adalah segala hal yang membuat hidup ini dan dunia kita dapat dipahami. Budaya adalah yang membuat segala sesuatu berbicara. Secara detail dikatakan oleh Bennet (1980) bahwa pengertian budaya adalah kebiasaan dan ritual yang mengatur dan menentukan hubungan sosial kita berdasarkan kehidupan sehari hari sebagaimana halnya dengan teks-teks tersebut (sastra, musik, televisi, dan film) dan melalui kebiasaan serta ritual tersebut dunia sosial dan natural ditampilkan kembali atau ditandai atau dimaknai dengan cara tertentu yang sesuai dengan konvensi tertentu.

\section{Metode Penelitian}

Penelitian ini adalah penelitian kualitatif dengan pendekatan deskriptif. Penelitian kualitatif adalah penelitian yang bermaksud untuk memahami fenomena tentang apa yang dialami oleh subjek penelitian secara holistik, dan dengan cara deskripsi dalam bentuk katakata dan bahasa pada suatu konteks khusus yang alamiah dan dengan memanfaatkan berbagai metode alamiah (Moleong, 2011:6).

Penelitian ini dilaksanakan pada Kecamatan Hu'u Kabupaten Dompu.

Sumber data dalam penelitian ini adalah data primer yang merupakan data yang diperoleh dari hasil pengamatan langsung (observasi) dengan pihak-pihak terkait. Dalam hal ini terkait dampak budaya asing yang masuk di Kecamatan Hu'u Kabupaten Dompu.

Untuk mengumpulkan data yang dibutuhkan dalam penulisan ini maka digunakan pengumpulan data sebagai berikut :

1. Penelitian Lapangan (Field Research)

a. Pengamatan (Observasi)

b. Wawancara (Interview)

Teknik analisa data yang digunakan dalam penelitian ini adalah analisis data kualitatif, mengikuti konsep yang diberikan Miles dan Huberman. Miles dan Huberman dan Saldana (2014), mengemukakan bahwa aktifitas dalam analisis data kualitatif dilakukan secara interaktif dan berlangsung secara terus menerus pada setiap tahapan penelitian sehingga sampai tuntas, dan datanya sampai jenuh. Aktivitas dalam analisis data, yaitu data reduction, data display, data reduction, dan conclusion drawing/verification.

\section{Hasil dan Pembahasan}

\section{Dampak Masuknya Wisatawan Asing}

Pengaruh negatif masuknya wisatawan asing bagi bangsa kita begitu besar terutama bagi sisi mental dan sosial kehidupannya, dikarenakan hal ini sangat berkaitan dengan hal demikian salah satunya adalah bawaan dari wisatawan asing. Berikut ini adalah beberapa dampak masuknya budaya asing dan pengaruhnya bagi masyarakat sekitaran pantai Lakey:

a) Gaya Hidup

Salah satu faktor yang paling berpengaruh adalah gaya hidup yang dimulai dari tingkah laku, gaya bicara, ataupun cara berhubungan dari para wisatawan asing yang ditiru oleh sebagian besar masyarakat lokal pantai Lakey. Gaya hidup bisa dilihat dari cara berpakaian seseorang, kebiasaanya dan lain lain. 
b) Fashion

Dampak lain dari masuknya wisatawan asing adalah fashion yaitu dari model berpakaian, model sepatu, model rambut bahkan cara berdandan pun menjadi tren yang banyak diikuti oleh masyarakat lokal pada umumnya. Banyak masyarakat Lakey yang mengikuti gaya fhasion selayaknya wisatawan asing dan melanggar norma keagamaan yang dianut oleh masyarakat sekitar pantai Lakey

c) Makanan

Dalam hal ini makanan pun sangat berpengaruh terhadap kehidupan masyarakat lokal, dikarenakan makanan asing yang lebih mudah dan enak seperti junk food ataupun makanan cepat saji lainnya, sehingga bisa menyingkirkan cita khas makanan dari budaya lokal. Hal ini dipengaruhi oleh wisatawan asing yang masuk ke Indonesia dengan tujuan untuk membuat makanan mereka laris dikalangan masyarakat lokal.

\section{Dampak Positif Masuknya Wisatawan Asing}

a) Perubahan tata nilai dan sikap

b) Pola pikir masyarakat masyarakat yang berubah dan menuju masyarakat yang modern berkembangnya ilmu pengetahuan dan juga teknologi, sehingga masyarakat bisa mengetahui informasi yang ada di Indonesia dan dunia.

c) Tingkat kehidupan yang lebih baik dalam perekonomian masyarakat sekitar pantai Lakey karena mata pencaharian masyarakat Lakey selain bertani adalah menjadi pemandu wisata, peselancar dan pengusaha home stay (penginapan) bagi masyarakat yang bermodal.

d) Mampu menguasai bahasa asing walau banyak masyarakat yang bahkan tidak lulus SMA.

Dilihat dari hal tersebut bahwa Lakey adalah salah satu tempat mata pencaharian paling utama bagi masyarakat kecamatan $\mathrm{Hu} u$ karena disana banyak masyarakat yang aktifitasnya banyak berkomunikasi dengan wisatawan asing. Sebagian masyarakat yang mempunyai aktifitas di pantai Lakey adalah sebagai pedagang, pemandu wisata, pengusaha hotel atau restoran.
Akan tetapi dari datangnya wisatawan asing tak jarang banyak masyarakat yang mengikuti gaya hidup maupun sifat dari wisatawan asing tersebut. Hal ini dapat mempengaruhi pola pikir maupun gaya hidup masyarakat. Seperti katanya bapak Halik umur 25 tahun bahwa:

" banyak masyarakat yang berubah sikap dan perilakunya di sekitar pantai Lakey. Mereka cenderung mengikuti budaya barat dan banyak masyarakat yang lupa dengan adat istiadat maupun norma yang mereka anut, mereka lebih liar dalam hal bergaul. Banyak para remaja yang tidak tau adat istiadat nenek moyangnya. Tapi dari adanya orang asing kita juga merasakan manfaat di bidang perekonomian" ( Rabu, 9 mei 2018)

Hal tersebut diperkuat oleh peselancar sekaligus pemandu wisatawan pantai Lakey yang bernama kevin 23 tahun pada tanggal 10 mei 2018 yang menyatakan bahwa:

"Tentu saja kita sebagai masyarakat yang hdup disekitar pantai Lakey sudah merasakan pengaruh dari adanya budaya asing namun kita menerima dengan baik adanya turis asing karena mereka adalah sumber utama dari kekuatan sektor ekonomi masyarakat sekitar pantai Lakey".(Kamis, 10 mei 2018)

Dari pernyataan kevin bahwa adanya wisatawan asing sangat berpengaruh besar pada masyarakat sekitar pantai Lakey, baik dampak positif maupun negatif yang dirasakan masyarakat, selain itu ada pula pernyataan dari pak Gerry selaku ketua anak pantai pada tanggal 11 Mei 2018 beliau menyatakan bahwa:

"pengaruh budaya asing semakin kuat dirasakan oleh masyarakat sehingga tata krama dan sopan santun sudah mulai hilang atau jarang diterapkan oleh para remaja, banyak para pemuda jaman sekarang yang menganggap orang tua sebagai temanya sendiri contohnya seperti mereka bergurau yang berlebihan ke orang yang lebih tua dari mereka, dalam hal inipun masih belum ada campur tangan pemerintah dalam menghadapi arus budaya barat yang mulai tersebar hingga di masyarakat luar sehingga budaya dan adat istiadat yang dulu kita gunakan pun sudah mulai hilang di kalangan para remaja" ( Jum'at, $11 \mathrm{Mei}$ 2018)

Perkembangan pariwsata khususnya di pantai Lakey, sangat mempengaruhi sektor ekonomi masyarakat sekitar pantai Lakey. Namun perkembangan ini belum secara menyeluruh ataupun menyentuh seluruh lapisan masyarakat desa Hu'u. Sampai saat ini 
perkembangan pariwisata di Dompu lebih berkonsentrasi di desa Hu'u tepatnya di pantai Lakey dusun Cangga. Akan tetapi biasanya di dunia pariwisata dikenal adanya musim-musim tertentu seperti misalnya high season (musim ramai) pada bulan Desember sampai Mei dimana kedatangan wisatawan akan mengalami puncaknya, ini akan menjadi keuntungan besar bagi masyarakat Lakey yang dibidang jasa, perdagangan dan pengusaha (hotel, restoran, dll). Dan dikenal juga dengan low sesion (musim sepi) pada bulan Juni sampai Oktober yang dimana pada musim ini bisa disebut dengan musim kemarau karena biasanya musim ini para wisatawan jarang datang berkunjung. Hal ini juga diungkapkan oleh ibu Wiwin 32 tahun pemilik Vivian Home Stay bahwa:

" banyak turis yang datang dari berbagai negara contohnya dari Australia, Amerika, Brazil, Newzeland, Inggris, Swedia. memang banyak masyarakat yang mengeluh karena tingkah laku para remaja semakin melonjak tidak bisa diatur, mereka suka ugal-ugalan, minum-minuman keras. Tapi ada juga keuntungan dari adanya turis asing karna mereka dapat memberikan kita keuntungan tersendiri" ( Senin, 14 Mei 2018)

Adapun pernyataan dari bapak Ishaka 34 tahun pengusaha restoran Fatmah menyatakan bahwa:

“ dari dampak positfnya masyarakat Lakey memang sudah banyak yang memiliki usaha sendiri seperti hotel, restoran dan masih banyak lagi. itu semua diakrenakan banyak turis yang datang tiap bulanya hampir kurang lebih 300 orang. Banyak masyarakat yang tidak memiliki peluang usaha atau tidak mau berusaha itu yang menjadikan mereka merasa tersingkirkan atau minder. Itu yang membuat mereka membedakan diri. Kalau untuk dampak negatif karena datangnya turis itu sangat banyak contohnya saja dari gaya berpakaian, hura-hura malah mereka menyontoh gaya hidup bule yang harusnya tidak bisa diikuti. Nggak ada mereka mengikuti jejak suksesnya bule". (Selasa, 15 mei 2018)

Dari penjelasan bapak Ishaka 34 tahun, bahwa masyarakat sekitar pantai Lakey lebih memilih membedakan diri antara si kaya dan si miskin itu yang membuat kesenjangan sosial diantara masyarakat Lakey. Serta mereka kebanyakan menyontoh gaya hidup bule yang seharusya tidak pantas diikuti, mereka lebih suka mengikuti hal negatif dari kedatangan turis asing dibanding hal positifnya.
Hal lain juga dijelaskan oleh ibu Nina 45 tahun pemilik warung nasi, beliau mengatakan bahwa:

" kebanyakan masyarakat ini suka membedabedakan apalagi orang kaya mereka jarang mau bergaul sama kita yang miskin. Kayak kita dibatasi untuk bergaul sama mereka. Kalau untuk dampak adanya turis asing sih sangat banyak, contohnya seperti kurangnya sopan santun dalam berpakaian, anak-anak juga suka mabukmabukan" ( Rabu, 16 Mei 2018)

Dari penjelasan tersebut bahwa masyarakat pantai Lakey lebih suka membeda-bedakan antara si kaya dan si miskin hal ini mengakibatkan kesenjangan sosial. Jika hal ini terjadi secara berlangsung maka akan mengakibatkan konflik sosial antar masyarakat, karena sebenarnya kesenjangan sosial juga akan menimbulkan sikap individualistis. Sikap individualistis adalah sikap yang merasa dirinya paling benar sehingga mereka tanpa sadar akan memerhatikan orang lain dan membandingkan dengan dirinya yang dianggap dirinya paling benar.

Adapun pernyataan dari bapak AD umur 47 tahun pemandu wisata pantai Lakey bahwa:

"banyak sekali dampak dari adanya turis asing itu mencakup dampak negatifnya kalau dampak positifnya memang ada tapi itu menjadi keuntungan tersendiri untuk kita, contoh dampak negatifnya yaitu seperti cara berpakaian, minuman keras dan lain yang tidak bisa saya sebutkan. Kalau untuk campur tangan pemerintah sampai saat ini tidak ada pemerintah yang peduli terhadap kita" (Rabu, 16 Mei 2018

Pengaruh budaya asing disebabkan oleh kontak kebudayaan, semakin intensif hubungan atau interaksi dengan masyarakat yang berbudaya, sehingga akan berpotensi menimbulkan dampak bagi budaya asli yang sudah ada di masyarakat pantai Lakey khususnya. Pengaruh negatif masuknya wisatawan asing bagi masyarakat Lakey begitu besar terutama bagi sisi mental dan sosial kehidupan masyarakat pantai Lakey. Hal ini sangat erat dengan dampak yang ditumbulkan tersebut. Hal ini salah satunya adalah bawaan dari wisatawan asing yang datang ke pantai Lakey. Menurut ibu Fatmah 54 tahun pemilik asli restoran Fatmah mengatakan bahwa:

" banyak sekali dampak negatifnya dibanding dampak positifnya kalau dilihat masyarakat yang dulu sama yang sekarang, mereka lebih suka menghambur-hamburkan uangnya, konflik antar 
masyarakat, bagi yang cewek-cewek suka berpakaian minim. Masyarakat biasa-biasa saja menghadapi hal ini bahkan sudah dianggap biasa saja" ( Kamis, 17 Mei 2018)

Efek adanya wisatawan asing memang sangat memprihatinkan bagi masyarakat yang kurang pengetahuan seperti masyarakat timur, mereka malah menganggap hal biasa saja ketika budaya aslinya sudah tidak lagi menjadi familiar bagi mereka. Sering kali budaya dijadikan momok tersendiri bagi mereka karena mereka tidak ingin mengikuti aturan adat istiadat atau budaya itu sendiri mereka ingin merasa bebas tanpa ada belenggu peraturan para leluhurnya. Seperti pernyataan saudara Alim 22 tahun sebagai anak pantai Lakey bahwa:

" kalau dilihat budaya kita sudah tidak bisa kita kenali lagi malah tidak ada para orang tua kita yang mengajarinya lagi, kayak seakan-akan sudah punah mungkin akibat dari dampak negatif budaya asing juga kali dan banyak banget anakanak ini yang mengikuti style (gaya) budaya barat, seperti yang kita ketahui gimana sih budaya barat atau para turis asing bergaya. Ada juga malah yang nggak berbusana saat mereka berjemur untuk turis-turis asingnya dan hal itu diikuti oleh kebanyak masyarakat lokal sehingga dampaknya dapat menimbulkan efek kriminalitas serta pelecehan seksual" ( Jum'at, 18 Mei 2018)

Dari penjelasan tersebut mengatakan bahwa budaya sli masyarakat $\mathrm{Hu}$ 'u pada umumnya masyarakat Dompu sudah tidak bisa mengenali budaya sendiri bagi para sebagian masyarakat hal ini sangat disayangkan jika tidak ada penanganan lebih serius baik dari pemerintah atau dari tetuah masyarakat. Sebagian masyarakat menganggap hal ini sepele dikarenakan meraka beranggapan bahwa sekarang adalah jaman modern sehingga mereka tidak ingin atau tidak mau lagi belajar tentang budaya aslinya sendiri. Seharusnya sebagai masyarakat pantai Lakey bangga dengan bermacam budaya yang kita miliki. Tetapi saat ini banyak beberapa dari masyarakat yang lebih suka pada kebudayaan yang datng dari turis asing. Menurut Febyandri 22 tahun sebagai anak pantai Lakey mengatakan bahwa:

" banyak sekali dampak dari masuknya turis asing contohnya yah seperti hidup bebas, para remaja semakin tidak terkontrol mereka lebih suka mabuk-mabukan apalagi yang punya teman bule otomatis mereka selalu mabuk-mabukan kayak ngikutin gayanya bule gitu. Yang paling disayangkan itu kenapa mereka nggak mengikuti jejak kesuksesanya bule malah mereka megikuti hal negatif dari bule tersebut. Sampai-sampai budaya kita sendiri sudah nggak mau dikenali" ( Jum'at, 18 Mei 2018)

Budaya asli memang banyak yang hampir punah dikarenakan banyak sekali budaya luar yang masuk dan diterapkan oleh masyarakat. Hal ini bukan dikarenakan masyarakat yang menyukai atau mempelajari budaya dari turis asing tersebut tetapi dikarenakan kurangnya pengenalan terhadap kebudayaan kita sendiri. Sebenarnya kita boleh menyukai atau mempelajari tentang budaya asing. Namun jangan sampai kita lupa dengan budaya kita sendiri, mungkin kebudayaan kita akan tetap bertahan sampai sekarang.

\section{Simpulan}

Berdasarkan hasil dari penelitian Dampak Adanya Turis asing Terhadap Masyarakat Lokal Sekitar Pantai Lakey Desa Hu'u Kabupaten Dompu dan dampak yang ditimbulkan akibat adanya turis asing di sekitar lokasi pantai Lakey, maka ditarik kesimpulan:

1) Tradisi gaya hidup kebarat-baratan salah satunya adalah cara berpakaian yang tidak sopan bagi para perempuan seperti memakai celana atau rok pendek serta baju yang tidak bisa menutup semua badan bahkan ada juga yang memakai bikini ( pakaian dalam saja). Mereka tidak merasa risih atau malu terhadap lawan jenisnya ketika mereka menggunakan pakaian pendek atau tidak menutup seluruh badanya. Hal ini dianggap biasa bagi mereka sehingga mereka merasa tidak takut dengan dampak dari berpakaian pendek.

2) Masih menerapkan pola hidup konsumtif sebagian masyarakat masih suka menghambur-hamburkan uang hanya untuk melakukan hal negatif seperti pesta minuman keras ketika ada acara-acara tertentu, mereka tidak enggan untuk mengeluarkan uang banyak hanya untuk mabuk-mabukan. Bukan hanya untuk membeli minuman keras mereka juga sering membeli kebutuhan yang tidak penting seperti membeli baju yang harganya cukup mahal hanya untuk menghabiskan uangnya saja.

3) Adanya turis asing juga mengakibatkan kesenjangan sosial, pada umumnya masyarakat pilih-pilih teman bergaul hal ini membuat masyarakat miskin merasa minder dengan masyarakat yang lebih mampu. Menurut tanggapan masyarakat 
pantai Lakey bahwa sebagian masyarakat yang bermmodal atau kaya mereka lebih mengurangi bergaul dengan yang kurang mampu karena dianggap mereka kurang berpengalaman dalam dunia bisnis. Sampai saat ini juga masih belum ada campur tangan pemerintah dalam menanggapi hal ini.

4) Namun dari sekian banyak dampak negatif yang dijelaskan oleh masyarakat Lakey ada juga dampak positif yang dirasakan oleh masyarakat yaitu terciptanya lapangan kerja dan lain-lain.

\section{Saran}

1. Para masyarakat terutama yang perempuan harus lebih menghargai diri sendiri sebelum menghargai orang lain. Seharusnya mereka bisa menutup auratnya karena memang pada dasarnya masyarakat Lakey bermayoritas Islam, seperti yang kita ketahui bahwa Islam adalah agama yang mampu menghargai diri sendiri dalam arti menutup aurat baik bagi perempuan dan laki-laki. Hal ini juga dapat mengurangi kriminalitas atau pelecehan seksual untuk kaum perempuan yang bisa menutup auratnya.

2. Hidup boros adalah hidup yang sangat merugikan untuk masa depan karena hal ini mengakibatkan kita berfikir bahwa uang hanya untuk dihabiskan pada saat itu juga tanpa berfikir bahwa kita masih punya hari esok. Lebih baik kita pergunakan uang tersebut untuk membeli keperluan yang dianggap penting karena kita hidup bukan untuk hari ini saja.

3. sikap individualistis yang saat ini sangat banyak diterapkan disetiap masyarakat pantai Lakey, sebenarnya sikap ini harus dijauhi karena akan menimbulkan hal-hal yang tidak diinginkan juga memicu adanya konflik antar masyarakat, apalagi masyarakat $\mathrm{Hu}$ 'u umumnya Dompu kerap sekali terjadi konflik antar masyarakat. Setidaknya jika kita tidak bisa menghentikan konflik tersebut kita bisa menghindari sikap individualistis.

\section{DAFTAR PUSTAKA}

[1] Arikunto (2010), "Metode Penelitian", melalui eprints.undip.ac.id, 12 mei 2018.

[2] Arikunto (2010),'Metodologi Penelitian”, Repistory.upi.edu, 24 mei 2018.

[3] Azwar, S (1999),"Metode Penelitian”, Pustaka Belajar,Yogyakarta, 21 mei 2018.

[4] Bennet(1980),'Pengertian Budaya dan Unsurunsur Budaya", melalui Hariannetral.com, 13 maret 2018.

[5] Berger(2014),'Pengertian Masyarakat", melalui dilihatya.com,17 mei 2018.

[6] Berger, L.P(2015),"Pengertian Masyarakat Menurut Para Ahli", melalui bgc.12blogspot.com, 15 januari 2018.

[7] Biederman (2007), "Kebijakan Pariwisata", melalui tentangpariwisata.blogspot.com, 23 juli 2018.

[8] Bogdan dan Biklen (2010),"Metodologi Penelitian", melalui eprints.uny.ac.id.

[9] Burkart and Medlik(1987), "Definisi Pariwisata Lengkap Menurut Para Ahli", melalui 23Tourisme.blogspot.co.id, 21 januari 2018.

[10]Cohen(1972),"Pengertian Wisatawan", Googleweblight.com, melalui Taufik Wordpress, 12 maret 2018.

[11]Fakih, M(2015),'Pengertian Masyarakat Menurut Para Ahli", melalui bgc.12blogspot.com, 09 april 3018.

[12]Fleuler (2010)," Definisi Pariwisata Menurut Para Ahli", melalui 23tourism.blogspot.com, 21 Januari 2018.

[13]Limbong, F dan Soetomo, $S$ (2014), "Dampak Perkembangan Wisata dan Lingkungan Taman Nasional Karimunjawa",melalui Ejournal3.undip.ac.id, 09 maret 2018.

[14] Gamal(2002), 'Pengertian Budaya dan Unsurunsur Budaya", melalui Hariannetral.com, 13 mei 2018.

[15]Gamal(2002),'Pengertian Pariwisata Menurut Para Ahli", melalui Googleweblight.com, 13 mei 2018.

[16] Gillin (2015),'Pengertian Masyarakat Menurut Para Ahli", melalui bgc.12blogspot.com, 09 maret 2018.

[17] Gunanto, E.Y, (2017),'Manfaat Pariwisata Goa Kreo Dan Waduk J-4:-... Bagi Perekonomian Dan Lingkun yarakat", melalui Https://Jurnal.untagsıy.ac.ıu, 06 maret 2018.

[18]Harold, J.L(2015),"Pengertian Masyarakat Menurut Para Ahli”, bgc.12blogspot.com, 2015. 
Heher(2003),"Pengertian Wisatawan", melalui Taufik Wordpress, 22 januari 2018

[19]Herskovits, M (2012)," Culture And Advertising', Article of Academia.edu, Institut Teknologi Bandung. 23 mei 2018

[20]Horton and Hunt (2015),"Pengertian Masyarakat Menurut Para Ahli", melalui bgc.12blogspot.com, 20 maret 2018.

[21]Hunziker and Krapt, K (1942),'Pengertian Pariwisata Menurut Para Ahli", melalui 23tourism.blogspot.com, 21 Januari 2018.

[22] Kodyhat(1998), "Definisi Pariwisata Lengkap Menurut Para Ahli", melalui 23Tourisme.blogspot.co.id, 21 januari 2018.

[23] Kusdianto(1996),"Pengertian Budaya dan Unsur-unsur Budaya", melalui Hariannetral.com, 21 april 2018.

[24] Kluckhonh, C (1953),'Tujuh Unsur Budaya",melalui 222fadhlan.wordpress.com, 22 april 2018.

[25]Krapt, K dan Hunziker (1996),'Pengertian Pariwisata Menurut Para Ahli", melalui 23tourism.blogspot.com, 21 Januari 2018.

[26] Maciver, R(2015),'Pengertian Masyarakat Menurut Para Ahli", melalui bgc.12blogspot.com, 12 mei 2018.

[27] Marpaung, H dan H. Bahar (2002), Pengantar Pariwisata, ALFABETA , Bandung, 21 mei 2018.

[28] Mathieson and wall(1982), "Definisi Pariwisata Lengkap Menurut Para Ahli", melalui 23Tourisme.blogspot.co.id, 21 januari 2018.

[29] Marx, $\quad \mathrm{K}(2015)$,'Pengertian Masyarakat Menurut Para Ahli”, melalui bgc.12blogspot.com, 22 mei 2018.

[30] Meyers, K (2009),'Definisi Pariwisata Lengkap Menurut Para Ahli", melalui 23Tourisme.blogspot.co.id, 21 januari 2018.

[31]Miles dan Huberman (2007),"Metodologi Penelitian", melalui eprints.uny.ac.id, 20 mei 2018.

[32] Murphy (1985),'Pengertian Wisatawan", Googleweblight.com, melalui Wordpress, 14 mei 2018.

[33] Mcintosh, R Dan S. Gupta (1996), "Definisi Lengkap Menurut Para Ahli", melalui 23tourism.blogspot.com, $21 \mathrm{Ja} \quad 3$.

[34]Nurdin, M (2012),'Dampak industri pariwisata pada lingkungan sosial budaya dan alam", Diunduh melalui www.Nurdinrazak.com, 12 mei 2018.

[35] Oktaviyanti, S.S (2013), "Dampak Sosial Budaya Interaksi Wisatawan dengan Masyarakat Lokal di Kawasan
Sosrowijayan"jurnal.ugm.ac.id/tourism_pariwis ata/article/download.

[36]Pangestu, E.M (2014),'Perkembangan Pariwisata Indonesia Paling Bagus", melalui Travel.kompas.com, Menparekraf, 1 April 2018.

[37]Pendit(1994),"Pengertian Pariwisata Definisi Jenis Promosi Wisatawan Menurut Para Ahli",melalui www.landasanteori.com, 22 mei 2018.

[38] Pendit(1994),"Pengertian Pariwisata Definisi Jenis Promosi Wisatawan Menurut Para Ahli", melalui www.landasanteori.com, 20 Mei 2018.

[39] Pendit(1994),'Pengertian Pariwisata Definisi Jenis Promosi Wisatawan Menurut Para Ahli”, melalui www.landasanteori.com, 20 Mei 2018.

[40] Pendit(1994),'Pengertian Pariwisata Definisi Jenis Promosi Wisatawan Menurut Para Ahli", melalui www.landasanteori.com, 20 Mei 2018..

[41]Pendit, N.S (1994)."Ilmu Pariwisata Sebuah Pengantar Perdana".Jakarta,PT Pradnya Paramita.

[42] Pendit (2002),"Pengertian Wisatawan", Googleweblight.com, melalui Taufik Wordpress, 20 mei 2018.

[43] Perda Dompu (2016),'Peraturan daerah Dompu nomor 7 tahun 2016", melalui jdih.dompukab.go.id. 2018.

[44]Pitana, I.G (1999).’Pelangi PariwisataBali.Kajian Aspek Sosial Budaya Kepariwisataan Bali di Penghujung Abad", Denpasar,BP.

[45]Pizam, A. and Milman, A(1984),"'The Social Impacts of Tourism”. Industry and

Environment

[46]Reid, A (1992)," Asia Tenggara Dalam Kurun Niaga 1450-1680 Jilid 1: Tanah Di Bawah Angin", Jakarta pusat, Yayasan Obor Indonesia, 1992.

[47]Richardson and Fluker (2004),'Definisi Pariwisata Lengkap Menurut Para Ahli", melalui 23tourism.blogspot.com, 21 Januari 2018.

[48] Sihite (2000),"'Pengertian Pariwisata Menurut Para Ahli", melalui 23tourism.blogspot.com, 21 Januari 2018.

[49] Soekadijo(1996),'Definisi Pariwisata Lengkap Menurut Para Ahli", melal ’ot.com, Blogger, Rabu 21 januari 201

[50] Soekadijo (1997),"Pengertian Wisatawan", melalui https://taufikzk.wordpress.com,1 february 2018.

[51] Soekanto, S(1990),"Masuknya Budaya Asing ke Indonesia", Makalah ISBD, 2018. 
[52] Soemardjan, S (2015),"Pengertian Masyarakat Menurut Para Ahli”, bgc.12blogspot.com, 2015. Sugiyono (2007),"Metodologi Penelitian", melalui repository.upi.edu, 21 februari 2018.

[53] Sugiyono (2010),"Metodologi Penelitian", melalui repository.upi.edu, 21 februari 2018.

[54] Sujana dan Ibrahim (1989),'Metode Penelitian", melalui repository.upi.edu, 2018.

[55] Sutherland, S.H (1990),'Dampak Masuknya Budaya Asing Ke Indonesia", ersa-melalui mahardhika.blogspot.com, 22 Maret 2018.

[56] Surwiyanta, A (2005),'Dampak Pengembangan Pariwisata Terhadap Kehidupan Sosial Budaya dan Ekonomi",Diunduh melalui amptajurnal.ac.id/index.php/MWS/article, 2018.

[57] Spillane, J.J (1982),'Definisi Pariwisata Lengkap Menurut Para Ahli", melalui 23Tourisme.blogspot.co.id, 21 januari 2018.

[58] Schulard, H.V (1996),'Definisi Pariwisata Lengkap Menuruti Para Ahli", melalui 23tourism.blogspot.com, 21 Januari 2018.

[59] Seo, U (1995),"Kambali Dompu Mantoi”, melalui https://kambalidompumantoi.wprdpress.com, 24 juli 2018.

[60] Wahab, S (1975),'Definisi Pariwisata Lengkap Menurut Para Ahli”, melalui 23Tourisme.blogspot.co.id, 21 januari 2018.

[61] Wahab dan Yoeti (1996),'Definisi Pariwisata Lengkap Menurut Para Ahli", melalui 23Tourisme.blogspot.co.id, 21 januari 2018.

[62] Williams, R (2009),'Konsep Budaya", melalui Jayapoken.blogspot.co.id,4 februari 2018. 